\title{
Aktivitas SGOT Dan SGPT Pada Penderita Malaria Falciparum Dan Malaria Vivax Di Puskesmas Hanura Kecamatan Teluk Pandan Kabupaten Pesawaran
}

\author{
Iwan Sariyanto \\ Prodi Diploma III Analis Kesehatan Poltekkes Tanjungkarang
}

\begin{abstract}
Abstrak
Penyakit Malaria bersifat endemik di daerah tropis dan subtropis. Plasmodium falciparum dan plasmodium vivax merupakan penyebab malaria terbanyak di Indonesia. Plasmodium falciparum menginvasi sel darah merah hingga mencapai 50\%. Pembesaran hati lebih sering ditemukan dari pada pembesaran limpa. Sedangkan pada plasmodium vivax menginveksi retikulosit, sehingga parasitemia biasanya terbatas sekitar 2-5\%, dapat terjadi relaps, karena maturasi hipnozoit yang tertinggal dalam hati. Serum Glutamic Oxaloacetic Transaminase (SGOT) dan Serum Glutamic pyruvic transferase (SGPT) merupakan enzim yang dapat digunakan untuk menilai cedera hati. Penelitian ini bertujuan untuk mengetahui aktivitas enzim SGOT dan SGPT pada penderita malaria falcipaum dan malaria vivax di puskesmas Hanura kecamatan Teluk Pandan Kabupaten pesawaran. Penelitian ini bersifat observasional analitik untuk membandingkan aktivitas enzim SGOT dan SGPT pada 50 penderita malaria falciparum dan 50 penderita malaria vivax yang diambil dengan cara consecutive sampling. Dianalisa menggunakan uji independen T-test. Hasil penelitian menunjukkan rata-rata aktivitas enzim SGOT pada penderita malaria falciparum lebih tinggi $(36,70 \mathrm{U} / \mathrm{L})$ dibandingkan dengan penderita malaria vivax (26.31 $\mathrm{U} / \mathrm{L}$ ), dan terdapat perbedaan yang bermakna dengan $p$-value $=0,000$. Didapatkan rata-rata aktivitas enzim SGPT pada penderita malaria falciparum lebih tinggi $(25,26 \mathrm{U} / \mathrm{L})$ dibandingakan dengan penderita malaria $\operatorname{vivax}(17,77 \mathrm{U} / \mathrm{L})$ dan terdapat perbedaan yang bermakna dengan $p$-value $=0,011$.
\end{abstract}

Kata kunci : SGOT, SGPT, malaria falciparum, malaria vivax

\section{SGOT And SGPT Activities In Malaria Falciparum And Malaria Vivax Patients At Hanura Health Center Teluk Pandan Sub District, Pesawaran District}

\begin{abstract}
Malaria is endemic in the tropics and subtropics. Plasmodium falciparum and Plasmodium vivax are the most common cause of malaria in Indonesia. Plasmodium falciparum infects red blood cells up to 50\%. Liver enlargement is more common than lymph node enlargement. While on Plasmodium vivax infects the reticulocytes, so parasitemia is usually limited to about $2-5 \%$, may occur relapse, due to hypnozoit maturation left in the liver. Serum Glutamic Oxaloacetic Transaminase (SGOT) and Serum Glutamic Pyruvic Transferase (SGPT) are enzymes that can be used to assess liver injury. This study aims to determine the activity of SGOT and SGPT enzymes in patients with falciparum malaria and vivax malaria in Hanura District Health Center. This was an observational analytic study to compare SGOT and SGPT enzyme activity in 50 patients with falciparum malaria and 50 vivax malaria patients taken by consecutive sampling. Analyzed using independent Ttest. The results showed that the average enzyme activity of SGOT in falciparum malaria patients was higher (36.70 U / L) compared with vivax malaria patients $(26.31 \mathrm{U} / \mathrm{L})$, and there was a significant difference with pvalue $=0,000$. Obtained average enzyme activity of SGPT in patients with falciparum malaria was higher $(25,26$ $\mathrm{U} / \mathrm{L})$ compared with vivax malaria patient $(17,77 \mathrm{U} / \mathrm{L})$ and there was significant difference with $\mathrm{p}$-value $=$ 0,011 .
\end{abstract}

Keywords : SGOT, SGPT, falciparum malaria, vivax malaria.

Korespondensi : Iwan Sariyanto, S.ST, M.Si, Jurusan Analis Kesehatan Politeknik Kesehatan Tanjungkarang, J1 Soekarno Hatta No.1 Bandar Lampung, Mobile 08127938215, e-mail sariyantoiwan@ yahoo.co.id 


\section{Pendahuluan}

Berdasarkan data WHO tahun 2015, malaria telah menyerang 106 negara di dunia. Diperkirakan ada 420.000 kematian akibat malaria, 99\% disebabkan oleh plasmodium falciparum dan plasmodium vivax (WHO, 2016). Di Indonesia menjadi penyebab kematian yang dominan terutama pada kelompok resiko tinggi yaitu bayi, balita, ibu hamil (Kementerian Kesehatan RI, 2013). Di Indonesia rata-rata kasus malaria klinis sebesar 15 juta per tahun dan $60 \%$ diantaranya terjadi pada usia produktif.

Morbiditas pada suatu wilayah ditentukan dengan Annual Parasite Incidence (API) per tahun atau Angka Parasit Malaria. API di Kabupaten Pesawaran dalam waktu lima tahun (2010-2014) berfluktuasi. Pada tahun 2010 yaitu 1,8 per 1.000 penduduk, lalu mengalami peningkatan yang cukup signifikan pada tahun 2011 sebesar 4,79 per 1.000 penduduk, kemudian meningkat kembali tahun 2014 menjadi 7,26 per 1000 penduduk. Kasus malaria tahun 2014 sebanyak 3.033 kasus. Kasus terbanyak berada di wilayah endemis malaria yaitu Puskesmas Hanura (789 kasus) dengan 3 kematian (Profil kesehatan Kabupaten Pesawaran, 2014). Hasil pemeriksaan sediaan darah terhadap 565 penderita malaria diperoleh penduduk tersebut menderita malaria tertinggi disebabkan oleh plasmodium falciparum sebanyak 302 kasus, plasmodium vivax sebanyak 246 kasus dan infeksi gabungan (mix) sebanyak 17 kasus (Dinas Kesehatan Provinsi Lampung, 2014).

Terdapat empat parasit penyebab malaria pada manusia yaitu: Plasmodium falciparum, plasmodium vivax, plasmodium malariae, plasmodium ovale. Plasmodium falciparum dan plasmodium vivax merupakan penyebab malaria terbanyak (Soedarto, 2011). Plasmodium falciparum adalah spesies malaria yang menginvasi sel darah merah hingga mencapai $50 \%$. Skizogoni lebih banyak terjadi pada organ-organ dalam (limpa, hati sumsum tulang dll) daripada di peredaran darah. Komplikasi yang berat dan fatal dari Plasmodium falciparum dapat terjadi selama infeksi berlangsung dan berhubungan dengan penyumbatan pembuluh darah tergantung organ yang terkena (Lynee, 1996). Pembesaran hati lebih sering ditemukan dari pada pembesaran limpa. Komplikasi ikterik lebih banyak timbul dibandingkan komplikasi lainnya, sehingga menyebabkan peningkatan aktivitas enzim Serum Glutamic Oxaloacetic Transaminase
(SGOT) dan Serum Glutamic pyruvic transferase (SGPT) (Harijanto, 2012).

Sedangkan pada plasmodium vivax menginfeksi retikulosit, sehingga parasitemia biasanya terbatas sekitar 2-5\%. Komplikasi berat jarang terjadi pada infeksi plasmodium vivax meskipun koma dan kematian mendadak atau gejala gejala serebral lainnya pernah dilaporkan (Lynee, 1996) Pada plasmodium vivax limpa dapat membesar sampai derajat empat atau lima, malaria selebral, edema tungkai disebabkan hipoalbuminemia. Selain itu pada malaria vivax dapat terjadi relaps, karena maturasi hipnozoit yang tertinggal dalam hati (Harijanto, 2012). Kejadian demam, pucat dan sakit perut pada palpasi lebih sering terjadi pada pasien malaria falciparum, sedangkan hepatomegali ringan dan splenomegali sebagian besar teramati pada malaria vivax. Perubahan biokimia ringan sampai sedang yang terjadi pada $25 \%$ penderitan malaria, sedangkan bilirubin normal pada malaria falciparum dan transaminase normal pada malaria vivax (Myriam et al, 2015). Terjadinya peningkatan aktivitas enzim SGOT pada malaria vivax (Pir et al, 2012)

SGOT dan SGPT merupakan enzim hati yang digunakan dalam pemeriksaan laboratorium untuk menilai cedera hati. Peningkatan aktivitas enzim hati dapat menggambarkan kerusakan sel hati atau adanya kolestasis. SGPT terdapat dalam sitoplasma pada kerusakan sitoplasma sel hati, enzimenzim ini akan meningkat. SGOT ditemukan dalam mitokondria dan sitoplasma, kadarnya akan meningkat pada kerusakan mitokondria sel hati (Sulaiman, 2012). Peningkatan aktivitas enzim SGOT dapat ditemukan pada kasus seperti alkoholik, radang pankreas, malaria, infeksi liver stadium akhir, adanya penyumbatan pada saluran empedu, kerusakan otot jantung. SGPT dianggap lebih jauh spesifik untuk menilai kerusakan liver kronik (Bastiyansyah, 2008). Penderita malaria mengalami peningkatan aktivitas enzim SGOT, SGPT, ALP, bilirubin, kreatinin dan urea yang signifikan (Godse RR, 2013).

Penelitian ini bertujuan untuk mengetahui aktivitas enzim SGOT dan SGPT pada penderita malaria falciparum dan malaria vivax di Puskesmas Hanura Kecamatan Teluk Pandan Kabupaten Pesawaran.

\section{Metode}

Penelitian ini bersifat observasional analitik dengan pendekatan cross sectional. 
Variabel penelitian terdiri dari kelompok penderita malaria falciparum, kelompok penderita malaria vivax, dan aktivitas enzim SGOT dan aktivitas enzim SGPT. Populasi penelitian adalah penderita yang terdiagnosa malaria falciparum dan malaria vivax ketika datang ke Puskesmas pada bulan Juli hingga September 2017. Sampel pada penelitian ini sebanyak 50 sampel dari masing-masing kelompok. Teknik pengambilan sampel dengan consecutive sampling dimana semua subjek yang memenuhi kriteria inklusi dimasukkan dalam penelitian hingga jumlah subjek penelitian terpenuhi (Dahlan, 2005). Adapun kriteria sampel adalah: Pasien yang datang ke ke Puskesmas Hanura pada saat penelitian dan dinyatakan positif menderita malaria falciparum atau malaria vivax, berdasarkan diagnosa laboratorium, pasien bersedia menjadi responden, tidak menderita penyakit hati, demam typoid atau demam berdarah serta tidak mengkonsumsi obat TBC.

\section{Hasil}

A. Analisis Univariat

Tabel 1. Distribusi frekuensi aktivitas enzim SGOT pada penderita malaria falciparum dan malaria vivax

\begin{tabular}{|c|c|c|c|c|}
\hline \multirow{2}{*}{$\begin{array}{c}\text { Jenis } \\
\text { Malaria }\end{array}$} & \multicolumn{4}{|c|}{ Aktivitas enzim SGOT U/L } \\
\hline & Mean & SD & Min & Maks \\
\hline $\begin{array}{l}\text { Malaria } \\
\text { falciparum }\end{array}$ & 36,70 & 19,422 & 10,9 & 100,1 \\
\hline $\begin{array}{l}\text { Malaria } \\
\text { vivax }\end{array}$ & 26,31 & 9,010 & 11,4 & 64,8 \\
\hline
\end{tabular}

Berdasarkan tabel 1 diketahui bahwa rata-rata aktivitas SGOT pada penderita malaria falciparum lebih tinggi yaitu sebesar $36.70 \mathrm{U} / \mathrm{L}$, sedangkan rata-rata aktivitas SGOT pada penderita malaria vivax sebesar 26,31 $\mathrm{U} / \mathrm{L}$.

Tabel 2. Distribusi frekuensi aktivitas enzim SGPT pada penderita malaria falciparum dan malaria vivax

\begin{tabular}{lcccc}
\hline \multicolumn{1}{c}{$\begin{array}{c}\text { Jenis } \\
\text { Malaria }\end{array}$} & \multicolumn{4}{c}{ Aktivitas enzim SGPT U/L } \\
\cline { 2 - 5 } & Mean & SD & Min & Maks \\
$\begin{array}{l}\text { Malaria } \\
\text { falciparum }\end{array}$ & 26,26 & 14,17 & 6,11 & 77,80 \\
$\begin{array}{l}\text { Malaria } \\
\text { vivax }\end{array}$ & 17,77 & 9,84 & 7,80 & 63,00 \\
\hline
\end{tabular}

Berdasarkan tabel 2 diketahui bahwa rata-rata aktivitas SGPT pada penderita malaria falciparum sebesar 25,26 U/L, sedangkan ratarata aktivitas SGPT pada penderita malaria vivax sebesar 17,77 U/L.
Bila dibandingkan dengan nilai normal enzim SGOT dan SGPT yaitu sebesar $>31 \mathrm{U} / \mathrm{L}$ maka penderita malaria falciparum dengan aktivitas enzim SGOT normal sebanyak 25 penderita $(50 \%)$ dan tidak normal sebanyak 25 penderita $(50 \%)$. Sedangkan pada penderita malaria vivax aktivitas enzim SGOT normal sebanyak 42 penderita (82\%) dan tidak normal sebanyak 9 penderita (18\%).

Penderita malaria falciparum dengan aktivitas enzim SGPT normal sebanyak 38 penderita (78\%) dan tidak normal sebanyak 12 penderita (24\%). Sedangkan pada penderita malaria vivax aktivitas enzim SGPT normal sebanyak 46 penderita (92\%) dan tidak normal sebanyak 4 penderita $(8 \%)$.

\section{B. Analisis Bivariat}

Tabel 3.Perbedaan aktivitas enzim SGOT pada penderita malaria falciparum dan malaria vivax di Puskesmas Hanura Kecamatan Teluk Pandan Kabupaten Pesawaran.

\begin{tabular}{lcccc}
\hline $\begin{array}{l}\text { Penderita } \\
\text { Malaria }\end{array}$ & Mean & SD & SE-Mean & p-value \\
\hline $\begin{array}{l}\text { Malaria } \\
\text { falciparum }\end{array}$ & 36,70 & 14,17 & 2.746 & \\
$\begin{array}{l}\text { Malaria } \\
\text { vivax }\end{array}$ & 26,31 & 9,84 & 1.274 & 0.000 \\
\hline
\end{tabular}

Berdasarkan tabel 3 menunjukkan nilai $p$ value 0.000 dan lebih kecil dari nilai $\mathrm{p}<0,05$, dengan demikian terdapat perbedaan yang bermakna antara aktivitas enzim SGOT pada penderita malaria falciparum dan penderita malaria vivax di Puskesmas Hanura Kecamatan Teluk Pandan Kabupaten Pesawaran.

Tabel 4.Perbedaan aktivitas enzim SGPT pada penderita malaria falciparum dan malaria vivax di

Puskesmas Hanura Kecamatan Teluk Pandan Kabupaten Pesawaran.

\begin{tabular}{lcccc}
\hline $\begin{array}{l}\text { Penderita } \\
\text { Malaria }\end{array}$ & Mean & SD & SE-Mean & p-value \\
\hline $\begin{array}{l}\text { Malaria } \\
\text { falciparum }\end{array}$ & 25,26 & 14,17 & 2,004 & \\
$\begin{array}{l}\text { Malaria } \\
\text { vivax }\end{array}$ & 17,77 & 9,84 & 1.392 & 0.011 \\
\hline
\end{tabular}

Berdasarkan tabel 4 menunjukkan nilai $p$ value 0.011 dan lebih kecil dari nilai $\mathrm{p}<0,05$ dengan demikian terdapat perbedaan yang bermakna antara aktivitas enzim SGPT pada penderita malaria falciparum dan penderita malaria vivax di Puskesmas Hanura Kecamatan Teluk Pandan Kabupaten Pesawaran. 


\section{Pembahasan}

Malaria merupakan suatu penyakit yang disebabkan oleh parasit plasmodium yang ditularkan pada manusia melalui gigitan nyamuk Anopheles. Kabupaten Pesawaran merupakan daerah endemis malaria, khususnya di sepanjang pesisir pantai di Kecamatan Teluk Pandan. Pada tahun 2015, kasus positif malaria terjadi hanya di 3 wilayah kerja Puskesmas. Puskesmas Hanura dengan jumlah kasus terbanyak yaitu 2.276 kasus, Puskesmas Pedada 320 kasus, dan Puskesmas Padang Cermin 116 kasus. Tingginya kasus malaria di wilayah tersebut karena kondisi alam yang memungkinkan banyaknya tempat perindukan nyamuk seperti hutan, laguna dan tambak terlantar (Profil Kesehatan Kabupaten Pesawaran, 2015).

Berdasarkan karakteristik responden menurut jenis kelamin dan umur penderita, penyakit malaria dapat menyerang semua jenis kelamin dan semua umur, tetapi kejadian malaria terjadi paling banyak pada jenis kelamin laki-laki dengan jumlah 53 penderita $(53 \%)$ dan kejadian malaria terbanyak pada usia 16-44 tahun dengan jumlah 35 penderita $(58,3 \%)$. Berdasarkan Profil Kesehatan Indonesia tahun 2013, usia 16-44 tahun tersebut tergolong usia produktif. Penderita malaria didominasi oleh jenis kelamin laki-laki dan pada usia produktif, karena pada jenis kelamin tersebut dan terutama pada usia produktif memiliki probabilitias lebih tinggi untuk tertular malaria melalui gigitan nyamuk di luar rumah (Pusdatin, 2016).

Sel-sel hati (hepatosit) apabila mengalami cedera cenderung membebaskan enzim aminotransferase (SGOT dan SGPT), enzim yang secara normal berada di dalam sel (intra sel) masuk ke dalam aliran darah dan akan terukur melalui pemeriksaan laboratorium (Sosrosumiharjo, 2012) Enzim SGOT dikeluarkan ke sirkulasi apabila terjadi kerusakan atau kematian sel. Tingginya kadar enzim ini berhubungan langsung dengan jumlah kerusakan sel. Kerusakan sel akan diikuti dengan peningkatan kadar SGOT dalam 12 jam dan tetap meningkat selama 5 hari (Sulaiman, 2012).

Hasil penelitian ini menunjukkan adanya perbedaan yang bermakna antara aktivitas enzim SGOT pada penderita malaria falciparum dan aktivitas enzim SGOT pada malaria vivax dengan $p$-value $0,000(\mathrm{p}<0,05)$. Hal ini sejalan dengan penelitian Wiadnya I.B.R, (2013) terdapat perbedaan yang bermakna p-value
0,00 ( $\mathrm{p}<0,05)$. Antara kadar SGOT pada penderita malaria falciparum dan malaria vivax, di RSUD Praya, Mataram. Berdasarkan statistik juga terdapat perbedaan yang bermakna antara aktivitas enzim SGPT pada penderita malaria falciparum dan aktivitas enzim SGPT pada malaria vivax dengan $p$ value $0,011(\mathrm{p}<0,05)$. Beberapa penelitian di negara endemis malaria seperti India dan Nigeria menunjukkan bahwa disfungsi hati adalah gambaran klinis malaria, kadar SGOT dan SGPT penderita malaria meningkat dan berbeda secara bermakna dibandingkan dengan kelompok kontrol (Ogbadoyi EO and Tsado RD. 2009 ; Shahnaz Shah et al., 2007) juga membuktikan dalam penelitiannya di India bahwa peningkatan transaminase (SGOT dan SGPT) merupakan salah satu cara untuk menegakkan diagnosa Hepatopati Malaria.

Aktivitas enzim SGOT dan SGPT pada malaria falciparum dan malaria vivax terdapat perbedaan, hal ini dimungkinkan karena pada malaria falciparum dan malaria vivax memiliki siklus hidup yang berbeda. Bila nyamuk anopheles mengandung parasit malaria menusuk hospes, sporozoit masuk ke aliran darah, dalam waktu $\pm 1 / 2-1$ jam sporozoit tiba di hati dan segera menginfeksi sel hati. Di sel hati sporozoit mengalami reproduksi aseksual yang disebut sebagai proses skizogoni atau proses pemisahan. Tahap skizogoni praeritrositik berlangsung selama 8 hari pada malaria vivax, dan 6 hari pada malaria falciparum.

Jumlah merozoit malaria falciparum yang berasal dari skizon matang kurang lebih 40.000 merozoit, pada malaria vivax membentuk kirakira 10.000 merozoit. Siklus preeritrositik dalam jaringan hati pada malaria falciparum hanya berlangsung satu kali, sedangkan pada malaria vivax sporozoit masuk ke dalam sel hati dan tumbuh menjadi skizon hati yang sebagian menjadi hipnozoit, dan dapat menimbulkan kekambuhan jika daya tahan tubuh menurun (Surontou, 2014).

Akhir fase praeritrosit skizon akan mengalami pecah, lalu merozoit keluar dan masuk ke dalam peredaran darah. Sebagian besar merozoit menyerang eritrosit yang berada di sinusoid hati. Saat sel hati cedera, enzim yang banyak ditemukan di sel parenkim hati akan dilepaskan kedalam peredaran darah sehingga terjadi peningkatan enzim aminotransferase di dalam darah (Sutanto, 2009).

Infeksi oleh Plasmodium falciparum merupakan yang terberat, karena parasit ini menyerang baik eritrosit maupun retikulosit, 
skizogoni berlangsung cepat dalam waktu 36 sd 48 jam. Dari satu eritrosit dihasilkan banyak merozoit (20-32 merozoit). Selain itu juga terjadi perubahan fisik pada eritrosit yang tidak dijumpai pada infeksi oleh plasmodium lainnya yaitu eritrosit yang terinfeksi lebih mudah saling melekat pada endotel kapiler, membentuk trombus (aglutinasi) eritrosit yang terinfeksi lebih tipis, lebih besar diameternya dan mudah pecah di dalam sistem retikuloendotelial (Zulkarnain, 1993).

Malaria falciparum dapat menginfeksi semua kelompok usia dengan beberapa komplikasi sistemik yang bervariasi pada kelompok usia yang berbeda. Hepatopati merupakan salah satu komplikasi malaria falciparum. Hepatopati Malaria dikaitkan dengan kejadian komplikasi yang lebih tinggi seperti gagal ginjal, syok, sindrom gangguan pernapasan akut dan hipoglikemia. (Rama Prakasha et al., 2012)

Aktivitas enzim SGOT biasanya sedikit meningkat pada tahap awal penyakit dan meningkat tajam selama fase paling akut. Peningkatan enzim SGOT juga bergantung pada saat waktu pengambilan sampel, yang menunjukan peningkatan keparahan penyakit dan kerusakan jaringan, SGOT yang menurun menunjukan pemulihan penyakit dan perbaikan jaringan. Kadar yang rendah sampai menengah, 2 sampai 5 kali nilai normal terjadi pada saat yang sama selama kondisi atau penyakit sebelumnya atau mungkin menunjukan anemia hemolitik, tumor hati yang bermetastasis, pankreatitis akut, emboli paru, dan perlemakan hati (Kowalak, 2010).

Hasil penelitian ini rata-rata aktivitas enzim SGOT pada penderita malaria falciparum sebesar 36,70 U/L dan $26.31 \mathrm{U} / \mathrm{L}$ pada penderita malaria vivax. Sedangkan ratarata aktivitas enzim SGPT pada penderita malaria falciparum $25,26 \mathrm{U} / \mathrm{L}$ dan $17,77 \mathrm{U} / \mathrm{L}$ pada penderita malaria vivax. Jika di bandingkan dengan nilai normal SGOT yaitu $<31$ U/L maka aktivitas enzim SGOT pada penderita malaria falciparum yang lebih dari normal sebanyak 25 penderita (50\%), sedangkan aktivitas enzim SGOT pada penderita malaria vivax yang lebih dari normal sebanyak 9 orang (18\%). Sedangkan aktivitas enzim SGPT jika di bandingkan dengan nilai normal SGPT yaitu <31 U/L maka aktivitas enzim SGPT pada penderita malaria falciparum yang lebih dari normal sebanyak 12 penderita (24\%), sedangkan aktivitas enzim SGPT pada penderita malaria vivax yang lebih dari normal hanya 4 orang (8\%). Berdasarkan hasil aktivitas enzim SGOT pada malaria falciparum didapatkan nilai rata-rata yang melebihi nilai normal, dengan hal tersebut maka diperlukannya perhatian yang lebih untuk penderita malaria falciparum.

Hasil penelitian ini sesuai dengan Darmawati dkk (2008) yang menunjukkan bahwa pada penderita malaria di RS Dr. Wahidin Sudirohusodo kadar SGOT, SGPT, ureum, dan kreatinin dalam batas normal, dengan demikian terjadinya kerusakan hati dan ginjal masih sedikit. Daya cadang fungsi hati sangat besar dan daya regenerasi sel hati sangat cepat sehingga kelainan yang ringan, baik kerusakan awal sel hati maupun kerusakan jaringan hati yang belum meluas $(<60 \%)$ akan menunjukkan hasil pemeriksaan laboratorium dalam batas normal. (Sosrosumiharjo, 2012). Pada kerusakan sel hati ringan, dimana sintesis enzim belum terganggu, akan dijumpai peningkatan aminotransferase (Sulaiman, 2012). Dengan peningkatan kadar enzim SGOT pada penderita malaria falciparum yang ringan tersebut dan kadar SGPT yang masih normal mengindikasikan kerusakan jaringan hati belum meluas. Berdasarkan hasil tersebut maka diperlukannya pemeriksaan SGOT pada penderita Malaria falciparum untuk digunakan sebagai prognosis kelainan hati. Menurut Myriam et al, (2015) perubahan biokimia ringan sampai sedang terjadi pada $25 \%$ penderita malaria, sedangkan bilirubin normal pada malaria falciparum dan transaminase normal pada malaria vivax. Sedangkan Pir et $a l$, (2012) menemukan adanya peningkatan aktivitas enzim SGOT pada malaria vivax.

Peningkatan aktivitas enzim SGOT juga dipengaruhi oleh penyakit lain seperti TBC (Bastiyansyah, 2008), hepatitis (Surontou, 2014), demam berdarah dengue (Sudoyo, 2009), demam typoid (Irianto, 2013). Selain itu peningkatan enzim SGOT juga dipengaruhi oleh derajat parasitemia. Derajat parasitemia dinyatakan sebagai persentase dari eritrosit yang terinfeksi parasit atau dinyatakan sebagai jumlah parasit yang ditemukan per mikroliter darah. Pada malaria nonfalciparum, parasitemia jarang melebihi $2 \%$, sedangkan pada malaria falciparum dapat mencapai $50 \%$. Jika seorang penderita malaria non imun mengalami hiperparasitemia $>5 \%$, hal ini menunjukan terjadinya penyakit malaria yang berat (Soedarto, 2011).

Malaria berat adalah penyakit malaria akibat infeksi Plasmodium falciparum disertai gangguan multisistem. WHO menetapkan kriteria diagnosis malaria berat, yaitu adanya 
satu atau lebih komplikasi seperti hiperparasitemia, malaria selebral, anemia berat, gangguan asam basa dan elektrolit, gagal ginjal, malaria biliosa, dan ikterus (Surontou, 2014).

Hal-hal yang dapat mempengaruhi peningkatan enzim SGOT seperti TBC, hepatitis, demam berdarah dengue, demam typoid dalam penelitian ini dapat dikendalikan, sedangkan gejala klinis seperti demam, dan derajat parasitemia tidak dikendalikan karena tempat penelitian tidak menginterpretasikan hasil dalam derajat parasitemia. Sehingga hal ini menjadi keterbatasan penelitian ini.

Simpulan dari penelitan ini adalah: Rata-rata aktivitas enzim SGOT pada 50 penderita malaria falciparum sebesar 36,70 U/L dan melebihi batas normal, serta 26.31 U/L pada malaria vivax dan masih dalam batas normal. Rata-rata aktivitas enzim SGPT pada 50 penderita malaria falciparum sebesar $25,26 \mathrm{U} / \mathrm{L}$, serta $17,77 \mathrm{U} / \mathrm{L}$ pada malaria vivax dan masih dalam batas normal.Terdapat perbedaan yang bermakna antara aktivitas enzim SGOT pada penderita malaria falciparum dengan aktivitas enzim SGOT pada penderita malaria vivax dengan $p$-value 0,000 . Terdapat perbedaan yang bermakna antara aktivitas enzim SGPT pada penderita malaria falciparum dengan aktivitas enzim SGPT pada penderita malaria vivax dengan $p$-value $=0,011$.

Saran yang dapat diberikan adalah: Perlunya pemeriksaan enzim SGOT pada penderita malaria falciparum, sehingga dapat digunakan untuk prognosis kerusakan hati, Perlunya penelitian lanjutan aktivitas enzim SGOT dan SGPT pada penderita malaria dengan memperhatikan tingkat keparahan penyakitnya.

\section{Daftar Pustaka}

1. Bastiyansyah E, 2008. Panduan Lengkap Membaca Hasil Test Kesehatan, Penebar plus Cetakan I, Jakarta.

2. Dahlan M. S. 2005. Besar Sampel dan Cara Pengambilan Sampel, Salemba Medika, Jakarta

3. Darmawati, Fitriani. M, Ruland DN Pakasi dan Harjoeno, 2008. Gambaran Fungsi Hati dan Ginjal Pada Penderita Malaria, IJCP\&ML:(15)1hal 1-42
4. Dinas Kesehatan Provinsi Lampung, 2015. Profil Kesehatan Provinsi Lampung tahun 2014.

5. Dinas Kesehatan Kabupaten Pesawaran, 2015. Profil Kesehatan Kabupaten Pesawaran tahun 2014.

6. Godse, Roshan Rajendra, 2013. Hematological and biochemical evaluation in malaria vpatients with clinical correlation, Kamala Nehru Education Society, Aurangabad India., IJRRMS (3) 4

7. Harijanto,P.N, Nugroho agung dkk, 2012. Malaria dari Molekuler ke Klinis. EGC. Jakarta

8. Irianto K. 2013, Mikrobiologi Medis, Alfabeta Bandung

9. Kementerian Kesehatan RI, 2013. Pedoman dan Tata Laksana Malaria di Indonesia, Depkes RI, Jakarta.

10. Kowalak, Jennifer P. William Welsh ; Alih Bahasa David Putra Jaya, Lydia I, Mandera. 2009. Uji Diagnostik Ed 3, Penerbit Buku Kedokteran EGC, Jakarata.

11. Lynee, S. 1996 . Diagnostik Parasitologi Kedokteran . Buku Kedokteran EGC, Jakarta .

12. Myriam Arevalo Herrera, Mary Lopez Perez, Luz Medina, Alberto Moreno, Juan B Gutierrez and Socrates Herrera. 2015. Clinical profile of Plasmodium falciparum and Plasmodium vivax infections in low and unstable malaria transmission settings of Colombia. Malaria Journal. (14) 154

13. Ogbadoyi EO and Tsado RD. 2009. Renal and Hepatic Dysfunction in Malaria Patients in Minna, North Central Nigeria. Online J Health Allied Scs; 8(3)

14. Pir. M A., Bikha Ram Devrajani, Saira Baloch and Marya Baloch. 2012. Serum Enzyme Activities in Patients with vivax Malaria and falciparum Malaria. Pakistan. International journal of multidisciplinary sciences and engineering. (3)11

15. Pusat Data Informasi Kementerian Kesehatan., 2016. Infodatin., Jakarta

16. Rama Prakasha S, Goswami Debabrata, and Ganesh Kumar Saya., 2012. Malarial Hepatopathy and Its Outcome in India. N Am J Med Sci. 4(10): 449-452.

17. Shahnaz Shah, Liaquat Ali, Rukhsana Abdul Sattar, Tariq Aziz, Tahir Ansari and Jamal Ara, 2007. Malarial Hepatopathy in Falciparum 
Malaria. Journal of the College of Physicians and Surgeons Pakistan 2009, Vol. 19 (6): 367370

18. Soedarto, 2011. Malaria, Epidemiologi Global, Plasmodium, Anopheles, Penatalaksanaan penderita malaria. Jakarta, Sagung seto.

19. Sulaiman. A, Akbar. N, (Ed) 2012, Buku Ajar Ilmu Penyakit Hati, CV Sagung Seto, Jakarta.

20. Sutanto Inge, Ismid Suhariah, dkk, 2008. Parasitologi Kedokteran, Jakarta, FKUI EGC

21. Sosrosumiharjo R, Giantini A, Yusra. 2012. Pemeriksaan Laboratorium pada penyakit hati, Di dalam sulaiman A, Nurul A (ed) Buku Ajar Ilmu Penyakit Hati, Sagung Seto Jakarta.

22. Sorontou Y, 2014. Ilmu Malaria Klinik. EGC. Jakarta

23. WHO, 2016. Word Malaria Report 2016.

24. Zulkarnain. I (1993). Malaria, di Dalam Soeparman (ed) Ilmu Penyakit Dalam. FKUI, Jakarta. 